DOI: 10.20472/IAC.2019.050.022

MOTSHIDISI LEKHU

Central University of Technology, Free State, South Africa

\title{
MAKING INITIAL TEACHER EDUCATION MEANINGFUL: PRE-SERVICE SCIENCE TEACHERS' DEVELOPMENT FOR EFFECTIVE TEACHING
}

\begin{abstract}
:
Every aspect of teachers' practice is not only affected by the teaching strategies they use in the classroom, but also their beliefs and attitudes. This exploratory study was aimed at exploring the development of pre-service beliefs about effective science teaching, and how the learning environment influences their teaching and learning as they transition from pre-service teachers in preparation for becoming professional teachers. A convenience sample of pre-service teachers enrolled for a 4-year teacher education programme at a University of Technology participated in the study. Data gathering instruments including the Teacher Beliefs about Effective Science Teaching (TBEST) questionnaire and Constructivist Learning Environment (CLES) survey were administered to participants. TBEST is an instrument that aligns teachers' views about science teaching and learning with their measure of self-efficacy, their attitudes towards science, their beliefs about science teaching environment and the nature of science. CLES was used to assess the degree to which the classroom climate is conducive to students connecting science subject matter to their prior knowledge. The findings revealed that an effort is required to support, enhance and improve the teaching and learning of science pre and post teacher training. This will help to establish the relationship between the participants' beliefs about learning as pre-service teachers and actual teaching practice. It is important to note that teachers' attitudes and beliefs about teaching and learning are critical, as these might inform and influence the type of teachers they will become. This has implications on teacher education efforts to improve science teaching and learning, involving professional development to deepen teacher content and pedagogical content knowledge, in the belief that enhancing teacher knowledge will lead to improved classroom practice.
\end{abstract}

\section{Keywords:}

confidence, preparedness, teaching practice, teacher training, beliefs 


\section{Introduction}

Every aspect of teachers' practice is not only affected by the teaching strategies they use in the classroom, but also their beliefs and attitudes. Teachers are expected to bring about change in their classrooms and schools as informed by their practice. However, change can either be impeded or facilitated by their beliefs and attitudes towards the teaching and learning of science. It is therefore imperative that initial teacher education programmes should focus on pre-service teachers' beliefs and attitudes towards effective science teaching by promoting inquiry based instructional strategies. These can be informed by training them to plan and organize their lessons effectively and the teaching methods to be employed. Recommended teaching methods caninclude amongst others, using a variety of techniques in teaching science, providing adequate opportunity for active work and encouraging learner activities during teaching and learning.

Meanwhile, efforts to improve science teaching and learning often involve professional development to deepen teacher content and pedagogical content knowledge, in the belief that enhancing teacher knowledge will lead to improved classroom practice. Initial teacher education can bridge this gap by promoting instructional strategies that will assist future teachers to practice learner-based teaching methods that will enhance inquiry. Teachers' attitudes and beliefs about teaching and learning are critical as well. Unless teachers are willing to change their instruction consistent with what they are learning during teacher training, classroom practice will not improve.

In the quest to adequately prepare pre-service science teachers for their future classrooms, they responded to surveys onTeacher Beliefs about Effective Science Teaching (TBEST) questionnaire and Constructivist Learning Environment (CLES). The study focused on their beliefs about effective science teaching as informed by their classroom environment in their preparation as future science teachers. Research has shown that classroom climate is one of the most important predictors of student achievement (Muijs and Reynolds, 1999; Wang, Haertel and Walberg, 1997). It is against this background that the initial teacher training classroom environment be investigated to establish its impact on pre-service teachers' beliefs about effective science teaching.

\section{Related literature and theoretical framework}

Pre-service teachers enter initial teacher education (ITE) programmes with their own prior experiences, thoughts, values and beliefs which have an impact on their professional development (Chan, 1999). These teacher education programmes play an important role in the development of teachers' beliefs about teachingand learning (Pajares, 1992; Hancock \&Gallard, 2004). Their belief about teaching and learning can be formed through the observations they make and the practices they perform over a long time period that begins the day a pre-service teacher starts his/her undergraduate education and it alsoinvolves vocational training (Harwood, Klopper, Osanyin\&Vanderlee,2013).

Macbeath (2012) describes these preconceived experiences as unconscious and latent models that students bringwith them when they start their training programmes (MacBeath 2012). These might be based on both positive and negative recollections of their 
experiences about the profession. The role of ITE therefore, is to ignite, rekindle and enhance these experiences where positive. On the contrary, negative experiences need to be extinguished. These 'ready-made' projects as pronounced by Ashby, Hobson,Tracey,Malderez, Tomlinson, Roper, Chambers, and Healyl (2008) that pre-service teachers enact play a significant role on the type of teachers they are to become.

What happens in the teacher training programme classroom, therefore, has huge impact to either empower or disempower the pre-service teachers on the potential future teachers they will become. It is for this reason that Cremeers and Rezigt's (1999) description of a classroom environment was deemed relevant for this study. The classroom environment, according to Creemers and Rezigt, is the setting in which student learning takes place. It concerns the classroom's physical environment, the social system, the atmosphere, and norms and values (Creemers and Rezigt, 1999). Learners or students in a classroom constitute a social system as they are individuals from demographic factors including gender, religious beliefs and affiliations, economic status, different backgrounds with different norms and cultures etc. The role of the teacher, in this regard, is to ensure that they assist learners to learn by setting up a situation in which learners can and will learn effectively. This then requires teachers to possess qualities of effective teaching. Williams (2010) characterised these qualities of effective teaching as outlined by the Framework for effective teaching in Figure 1 below:

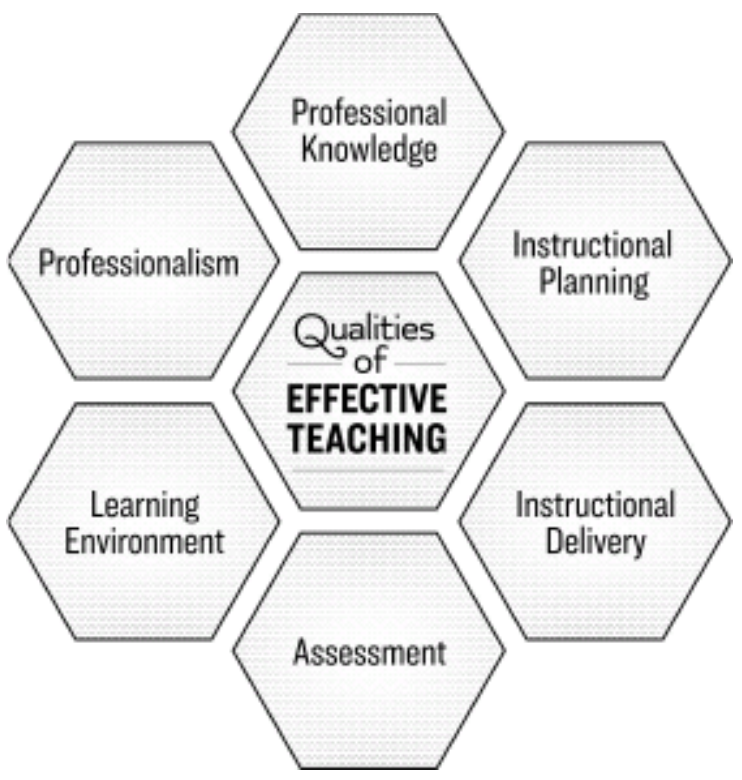

Figure 1: Framework for Effective Teaching (Williams, 2010)

It goes without saying that the learning environment forms a basis of how all the other qualities can be effected to achieve effective teaching. Since this study is grounded on the Constructivism theory, it qualifies the classroom under investigation to be evaluated if it qualifies to be a constructivist learning environment. The following characteristics of a constructivist classroom were taken from an online resource on Constructivism, Pedagogy in action: the SERC portal for educators on Constructivist learning

The characteristics of a Constructivist Classroom taken from this underlying link https://serc.carleton.edu/sp/library/sac/constructivist.htmlare given below from point 1 to 5 : 
1. Interactions between teacher-student and student-student are equally important in the learning process.

2. The roles and responsibilities of student and teacher fluidly pass back and forth between the two parties. While the teacher is ultimately responsible for creating an environment conducive to learning, students also share in the responsibilities associated with creating and responding to a learning environment.

3. Knowledge worth teaching/learning is broadly encompassing of factual, conceptual, and procedural types of knowledge. Prior knowledge of students is acknowledged and actively incorporated into the enacted curriculum. Questions whose answers may or may not be known by the teacher are welcomed and explored; and become integrated into the instructional dialogue of the classroom.

4. The classroom environment of a constructivist classroom is safe: intellectually, emotionally, and physically. Students look forward to spending time in the classroom because they are known, their idiosyncrasies are accepted, and their interests are important in the dynamics of the classroom.

5. Diverse instructional and assessment strategies are used which focus on conceptual understanding and reinforce the balance between teacher and student dynamics.

These above attributes of a constructivist classroom resonate with the title of this study that aims to make initial teacher education meaningful by investigating the pre-service teachers' development towards effective teaching. The special focus was on how teacher education programmes can lead to specially designed learning environments that can empower and influence learning. This in turn will empower pre-service teachersto better handle their future classrooms and further create conducive learning environments. Nissim, Weissblueth, ScottWebber and Amar (2016) purport that teachers see the concept of a learning environment as a complex that defines the element of teaching-learning and evaluation processes. This complex includes several factors: teacher, learner,teaching-learning task, learning process, style of learning, type of interaction between teacher and learner, duration of learning, extent of heterogeneity of the learner group, etc (Nissim et. al., 2016). Consequently, pre-service teachers will be better equipped to practice effective teaching.

\section{Aim of the study}

The main purpose of this study was to explore the development of pre-service teachers' beliefs about effective science teaching, and how the learning environment influences their teaching and learning as they transition from pre-service teachers in preparation for becoming professional teachers.

Research questions

The following are the research questions

- What are pre-service science teachers' perceptions about effective science teaching?

- How does the learning environment influence their teaching and learning? 
- To what extent can teacher education programmes enhance teachers' beliefs about effective science teaching and learning environment?

\section{Methodology \\ Research design}

This study used a non-experimental, descriptive and exploratory quantitative design to explorepre-service Physical science teachers' perceived beliefs about effective science teaching and how the learning environment influences teaching and learning. The purpose of an exploratory approach isto use initial, qualitative phase to identify ideas and beliefs to design the quantitative part of the study, whilea descriptive approach assesses the nature of existing conditions and provides a summary of an existingphenomenon by using numbers to characterize a group (McMillan \& Schumacher, 2006).

\section{Sample}

The participants were third year Bachelor of Education science students at a University of Technology. A convenience sample ofpre-service teachers enrolled for a 4-year teacher education programme at a University of Technology participated in the study.

\section{Data collection techniques}

\section{Instruments}

Data gathering instruments including the Teacher Beliefs about Effective Science Teaching (TBEST) questionnaire and Constructivist Learning Environment (CLES) survey were administered to participants.

The Teacher Beliefs about Effective Science Teaching (TBEST) is an instrument that aligns teachers' views about science teaching and learning with their measure of self-efficacy, their attitudes towards science, their beliefs about science teaching environment and the nature of science. It was adapted and adopted for use in this study.TBEST is made up of 21 items categorised into three factors namely, (1) Learning-Theory-Aligned Science Instruction; (2) Confirmatory Science Instruction and (3) All Hands-on All the Time. Factors 1, 2 and 3 have 11,7 and 3 items respectively. It is a 6-point Likert Type scale ranging from $1=$ strongly disagree to 6 = strongly agree. The instrument was tested for correlation between the factors and reliability. First, the factors were not highly correlated with each other, suggesting distinct constructs. Furthermore, the reliabilities (Cronbach's alpha) of the composites for each grade range (elementary, middle and high) are above 0.70 . These findings were consistent across all grade ranges and the overall grade.

Constructivist Learning Environment (CLES) survey was used to assess the degree to which the classroom climate is conducive to students connecting science subject matter to their prior knowledge. The CLES used is made up of 30 items categorised into five namely, personal relevance, learning about science, critical voice, shared control and student 
negotiation. Students' perception of the subject matter was measured on all five categories using a 5 -point Likert type scale ranging from $1=$ never to $5=$ always.

\section{Data analysis}

Data were analysed using GraphPadQuickStats and Microsoft Excel. Descriptive (means were used to indicate the average score)statistics for the categories of both scales were generated.

\section{Ethical issues}

Permission to conduct the study was sought from and approved by the institution. Consent was sought from the participants and it was explained participation in the study was voluntary. The benefits of participating in the study were explained to the participants. The respondents were also assured of the confidentiality of their responses.

\section{Findings and discussion}

This section presents the findings and discussion of each of the two data collection instruments used. The first one is on the TBEST, where an average mean per factor is given and a brief discussion follows. A similar approach is also followed for the CLES survey.

Table1: Descriptive summary of TBEST

\begin{tabular}{|l|l|}
\hline Factor & Average mean \\
\hline Learning-Theory-Aligned Science Instruction & 5.12 \\
\hline Confirmatory Science Instruction & 5.17 \\
\hline All Hands-on All the Time & 2.9 \\
\hline
\end{tabular}

The average means for the three factors of TBEST namely, learning-theory-aligned science instruction; confirmatory science instruction; and all hands-on all the time are given on Table 1 above. The following section gives a discussion on each of the categories

In learning-theory-aligned science instruction, science teachers and their beliefs may play a major role in science education reform since science teachers' beliefs lead to actions, and these actions ultimately impact on students (Clark \& Peterson, 1986). This critical relationship between the beliefs of teachers regarding implementation of science education reform efforts and instructional decisions has beendocumented (Czerniak, Lumpe, \& Haney, 1999; Czerniak\&Lumpe, 1996). According to Bandura (1997) beliefs are thought to be the best indicators of the decisions people make throughout their lives.

Confirmatory science instruction is a factor that was scored the highest of the three with an average mean of 5.17. The importance of using activities that have already been taught is important in identifying learners' prior knowledge and linking the old and the new knowledge. This will also assist in making connections to the learners' worlds and worldviews.

It should be noted thatall hands-on all the time factor is the lowest scored of the three factors. It comes as a no surprise as most of the pre-service teachers were not exposed to practical work during their schooling years. Where they are exposed to laboratory 
experiments during their initial teacher training, they mostly conduct step-by step predetermined laboratory activities. This traditional method limits their belief and confidence towards practical work. This finding agreeswith the findings of the study conducted by Kubota in 1997, where teachers have participated in laboratory science courses usually requiring them to conduct experiments that have pre-determined conclusions and are presented in a 'cookbook' fashion (Kubota, 1997). This approach is contrary to the constructivist belief about teaching which emphasises that students should be allowed to think of solutions to practical problems themselves before the teacher show them how they are solved; and they learn best by finding solutions to problems on their own.

Although pre-service teachers have learner-centred teaching and learning beliefs, they may not be able to implement their beliefs into their classroom practice because of the inadequate practical knowledge needed in the classroom. It is no surprise then, that many of the science teachers tend to close their classroom doors to their colleagues, ignore the rich sources outside the classroom, focus on the textbook, and teach to the examination.

Table 2: Descriptive summary of the CLES categories

\begin{tabular}{|c|c|c|c|c|c|c|}
\hline Category & $\begin{array}{l}\text { Description } \\
\text { (The extent to which the lecturer:) }\end{array}$ & Mean & Min & $\operatorname{Max}$ & Range & $\begin{array}{l}\text { Rank } \\
\text { order }\end{array}$ \\
\hline $\begin{array}{l}\text { Personal } \\
\text { relevance }\end{array}$ & $\begin{array}{l}\text { Relates science to students' out of } \\
\text { class experiences, and ensuring that } \\
\text { they can relate to their lives }\end{array}$ & 3.49 & 1.50 & 4.37 & 2.87 & 3 \\
\hline $\begin{array}{l}\text { Learning } \\
\text { about } \\
\text { science and } \\
\text { science }\end{array}$ & $\begin{array}{l}\text { Makes students to know the provisional } \\
\text { status of science knowledge, that it is } \\
\text { arranged or existing for the present, } \\
\text { possibly to be changed later }\end{array}$ & 3.29 & 2.29 & 3.29 & 1.00 & 4 \\
\hline $\begin{array}{l}\text { Critical } \\
\text { voice }\end{array}$ & $\begin{array}{l}\text { Gives students the opportunity to } \\
\text { question and criticize her pedagogical } \\
\text { plans and methods }\end{array}$ & 4.20 & 3.64 & 4.50 & 0.90 & 1 \\
\hline $\begin{array}{l}\text { Shared } \\
\text { control and }\end{array}$ & $\begin{array}{l}\text { Allows students to participate in } \\
\text { planning, conducting and assessing of } \\
\text { science learning }\end{array}$ & 3.08 & 2.54 & 3.61 & 1.07 & 5 \\
\hline $\begin{array}{l}\text { Student } \\
\text { negotiation }\end{array}$ & $\begin{array}{l}\text { Grants opportunities for students to } \\
\text { explain and justify to other students } \\
\text { their newly developing ideas and to } \\
\text { reflect on the viability of other students' } \\
\text { ideas }\end{array}$ & 3.89 & 3.61 & 3.97 & 0.36 & 2 \\
\hline $\begin{array}{l}\text { Overall } \\
\text { mean }\end{array}$ & & 3.59 & & & & \\
\hline
\end{tabular}

The revised CLES was adopted and adapted for use as a data collection instrument in this study where pre-service science teachers' perceptions of their actual teacher training classroom learning environment were measured. The five categories viz; personal relevance, learning about science, critical voice, shared control and student negotiation average means are given in Table 1 above. The following section gives a discussion on each of the categories 
Shared control was the lowest scored category with mean $=3.08$. This means that theextent to which the lecturer allows students to participate in planning, conducting and assessing of science learning can also be noted. Invariably, students cannot assist the lecturer in planning what to teach because they lack the relevant knowledge and do not know what they should know exactly (Acat, Anilan, \& Anagun, 2010)

The findings of this study are partially consistent with the research of Saban, Erdem and Demirel where the understanding that in constructivist learning environments, the teacher lets students direct their reactions, experiences, thoughts and interests into the lessons and change teaching strategies and content; encourages them to communicate with both him or her and among themselves; and steers them towards asking each other meaningful questions (Erdem\&Demirel, 2002; Saban, 2003) has not been put into practice. Conversely, teachers felt that the students are inexperienced to use shared control thus causing classroom management problems (Ongowo, 2013).

The category addressing critical voice was scored the highest with an average mean $=4.20$. This category deals with the extent to which the lecturer gives students the opportunity to question and criticize her or his pedagogical plans and methods. The highest mean score was achieved for the critical voice, meaning that the lecturer allows the students to question her pedagogical plans and methods to express concerns about impediments to their learning and at the same time, allows students to share with her the control of the learning environment. This finding is in agreement with the findings of the study conducted with the Thai Chemistry student teachers (Udomkan, Suwannoi, Chanpeng, \&Yuenyong, 2015). On the contrary, in a study conducted by Ongowo (2013) whereby the Teacher Perception Questionnaire (TPQ) which is a modified version of Constructivist Learning Environment Survey (CLES), the teachers' version was administered to practicing teachers. In that study, the teachers did not give their students the liberty to have a critical voice (Ongowo, 2013). This notable difference where CLES was administered to pre-service and practicing teachers should be acknowledged, because teachers in their own nature wouldn't expect learners to question their methods as in the African context, questioning the teachers' pedagogical strategies is likely to be perceived as indiscipline by the teachers and in such an environment; teachers are less likely to share authority in the classroom (Ongowo, 2013). In this study, even though the critical voice was scored the highest, it should be noted that students still felt that it was not acceptable for them to question the way that they were taught $(M=3.64)$, but rather to talk about activities that are confusing $(M=4.50)$. This is an indication that they are content with their lecturer's teaching methods and strategies.

Student negotiation covers the extent to which opportunities exist for students to explain and justify to other students their newly developing ideas and to listen to and reflect on the viability of other students' ideas. This category was ranked the second with a mean score $=$ 3.89. It seemed that the students considered that their lecturer provided a constructivist classroom learning environment at 'sometime' level towards a 'seldom' level. Items 25 ("I have a chance to talk to other students") and 26 ("I discuss how to solve problems with other students") where scored the highest with means of 4.25 and 3.97 respectively. This finding revealed that the lecturer creates classroom learning environments that encourage students to discuss their feeling and ideas to fellow students. This, according to Etiga and Nwala (2013) is a welcome development in science classrooms especially when students are made to participate in activities such as role playing and small groups' projects. The more students struggle to express their feelings and ideas to one another, the more they build consensus and collaboration. 
The category of personal relevance could be defined as the extent to which the lecturer relates science to students' out-of-class experiences and ensuring that students can relate what they learn in the science course is relevant to their lives. The statement "what I learn has nothing to do with life beyond my professional setting" is a negative statement and was scored the lowest $(M=1.50)$ of all the items in the full scale. When reverse scored, the mean found was 4.41, which indicates that the classroom learning environment is emphasizing relevance to everyday life.

This result is not surprising in that the goal of the science curriculum is to promote meaningful learning in science classroom that will equip the learner to survive in this world of science and technology. To this end every science teacher is challenged to connect science content with student's daily life experiences, hence it is imperative to enhance constructivist teaching and learning which should aim at promoting inquiry-based learning.

Uncertainty of sciencerepresents the extent to which the lecturer makes students to know the provisional status of science knowledge, that it is arranged or existing for the present, possibly to be changed later. The following items were scored the lowest "I learn that science cannot provide perfect answers to problems" $(\mathrm{M}=2.29)$, and "I learn that modern science is different from the science of long ago" $(M=2.86)$. Through these scores, the students still feel that the science that they are learning hasn't changed much from the old one and lacks practical application to problems at hand. Therefore, the lecturer should find ways to make content more relevant and more applicable to daily challenges. This finding, according to Etiga and Nwala (2013) confirms the fact that our science classrooms are still very traditionally oriented with greater emphasis on passing cognitive examination rather than constructing meaningful knowledge.

\section{Conclusion}

Teachers' beliefs, practices and attitudes are important for understanding and improving educational processes. Therefore, teacher education programmes should train teachers to promote constructivist learning environment which will encourage moving away from the traditional lecture style mode of instruction which emphasises lower order cognitive skills such as recall. Thus, an effort is required to support, enhance and improve the teaching and learning of science pre and post teacher training. 


\section{References}

Acat, B. M., Anilan, H., \& Anagun, S. (2010, April). The problems encountered in designing constructivist learning environments in science education and practical suggestions. The Turkish Online Journal of Educational Technology, 9(2), 212-220.

Ashby, P., Hobson, A., Tracey, L., Malderez, A., Tomlinson, P., Roper, T., Chambers, G. and Healy, J.(2008). Beginner Teachers' Experiences of Initial Teacher Preparation, Induction andEarly Professional Development: A review of literature. Research Report no.DCSF-RW076.London: Department for Children, Schools and Families.

Bandura, A. (1997). Self-efficacy in changing societies. (A. Bandura, Ed.) New York. USA: Press Syndicate of the University of Cambridge.

Chan, J. K. S. (1999). Student teachers' beliefs. What have they brought to the initial teacher training. Hong Kong: ERIC DocumentReproduction Service No. ED435607

Clark, C., \& Peterson, P. (1986). Teachers' thought processes. In M. Wittrock [Ed,], Handbook of research on teaching, (3rd ed.), (pp. 255-296). New York:Macmillan.

Creemers, B. P. M. \&Reezigt, G. J. (1999), "The Role of School and Classroom Climate in Elementary School Learning Environments", in H.J. Freiberg (wd.), School Climate:Measuring,Improving and Sustaining Healthy Learning Environments, Falmer Press,London

Czerniak, C. M., \&Lumpe, A. T. (1996). Relationship between teacher beliefs andscience education reform. Journal of Science Teacher Education, 7, 247-266.

Czerniak, C. M., Lumpe, A. T., \& Haney, J. J. (1999). Supporting the implementationof inquiry-based elementary science programs: Setting the stage for localreform. Electronic Journal of Science Education, 3 (4), 40-52.

Erdem D \&Demirel 2002. Constructivism in curriculum development. HacettepeUniversiteit EğitimFakültesiDergisi, 23, 81-87.

Etiga AJ \&Nwala L 2013. Secondary School Students' Perception of the Constructivist Learning Environment of Chemistry in Bayelsa State Nigeria. Siren Journals, 5(5).

Hancock, E. S., \&Gallard, A. J. (2004). Preservice science teachers' beliefs about teaching and learning: The influence of K-12 field experiences. Journal of Science TeacherEducation, 15(4), 281-291.

Harwood, D., Klopper, A., Osanyin, A. \&Vanderlee, M. 2013. It's more the care: earlychildhood educators" concepts of professionalism and development, 33(1):417.http://dx.doi.org/10.1080/09575146.2012.667394

Kubota, C. (1997). Preparation and professional development ofK-12 science teachersin the United States. Peabody Journal of Education. 72 (1), 129-143. 
MacBeath, J. (2012). Future of Teaching Profession. Education International Research Institute.

McMillan, J.H. \& Schumacher, S. (2006). Research in education: Evidence-basedinquiry (6th ed.). United States of America: Pearson Education.

Muijs, D. \& Reynolds, D. (2002). Classroom factors and student achievement in primarymath. AERA. New Orleans.

Ongowo, R. O. (2013, June). Secondary School teachers' Perceptions of a Biology Constructivist Learning Environment in Gem District, Kenya. International Journal of educational Research and Technology, 4(2), 01-06.

Nissim, Weissblueth, Scott-Webber and Amar (2016). The Effect of a Stimulating Learning Environment on Pre-Service Teachers' Motivation and 21st Century Skills. Journal of Education and Learning Vol. 5, No. 3 (30)

Pajares, F. (2002). The development of academic self-efficacy. In A. Wingfield \& J.Eccles (Eds). Development of achievement motivation. San Diego: AcademicPress.

Pedagogy in action: the SERC portal for educator. Online Resources on Constructivism https://serc.carleton.edu/sp/library/sac/constructivist.html

Saban, A. (2003). Learning-teaching process, Ankara: Nobel Publications.

Udomkan W, Suwannoi P, Chanpeng P andYuenyong C (2015). Thai Pre-service Chemistry Teachers' Constructivist Teaching Performances. Mediterranean Journal of Social Sciences, 6(4), 223-232.Wang, Haertel and Walberg, 1997

Williams, R. E. (2010). Administrator and teacher perceptions of the qualities of effective teacher. Unpublisheddoctoral dissertation, The College of William and Mary, Williamsburg, VA 